\title{
AMBIGUITAS DIFERENSIASI AGAMA DAN NEGARA DI INDONESIA
}

\author{
Binsar Antoni Hutabarat \\ Reformed Center for Religion and Society
}

\begin{abstract}
This article entitled, "The Ambiguity of the Differentiation between Religion and Nation in Indonesia" focuses on discussing how the relationship between religion and nation is not subduing one another. First of all, it is discussed about the latest research on the relationship between religion and nation, and its theoretical basis as the foundation, then the theory of differentiation between religion and nation also discussed as the best middle way of the relationship between religion and nation that is not subduing one another. After that, it is also discussed about the concept of differentiation between religion and nation according to Pancasila, and the ambiguity happened towards the policy of differentiation between religion and nation in Indonesia. In this writing, it is found that the differentiation between religion and nation according to Pancasila has a strong theoretical basis and relevant in Indonesian context. It is only that the impact of the ambiguity of differentiation still causes discriminative action to certain religion.
\end{abstract}

KEYWORDS: ambiguity, differentiation, religion and nation, Pancasila

ABSTRAK: Artikel yang berjudul "Ambiguitas Diferensiasi Agama dan Negara di Indonesia" ini fokus membahas mengenai bagaimana hubungan agama dan negara yang tidak saling menaklukkan. Pertamatama akan dipaparkan mengenai riset-riset mutakhir mengenai hubungan agama dan negara dan dasar teori yang mendasarinya, selanjutnya akan dipaparkan tentang teori diferensiasi agama dan negara sebagai salah satu jalan tengah terbaik tentang hubungan agama dan negara yang tidak saling menaklukkan. Setelah itu akan dipaparkan juga konsep diferensiasi agama dan negara menurut Pancasila, dan 
ambiguitas yang terjadi terhadap kebijakan diferensiasi agama dan negara di Indonesia. Di dalam tulisan ini ditemukan bahwa pembedaan agama dan negara menurut Pancasila memiliki dasar teori yang kuat, dan relevan dalam konteks Indonesia. Hanya saja dampak dari ambiguitas diferensiasi menyebabkan masih terjadinya tindakan diskriminasi terhadap agama tertentu.

KATA-KATA KUNCI: ambiguitas, diferensiasi, agama dan negara, Pancasila

\section{Pendahuluan}

Konflik antaragama dan negara, maupun antara agama dan agama merupakan realitas pada banyak negara. Pada satu sisi, negara sekuler yang mendasari pandangannya pada keyakinan bahwa pelan-pelan agama akan kehilangan pengaruhnya ternyata tidak didukung bukti yang kuat. Hingga saat ini realitas menunjukkan bahwa agama masih memiliki pengaruh di dalam kehidupan pribadi dan masyarakat. Pada sisi yang lain, negara yang menempatkan agama tertentu sebagai agama negara terbukti telah mendiskriminasikan agama tertentu. Dengan demikian dapat dikatakan bahwa agama dan negara tampaknya tidak dapat dipisahkan, namun agama dan negara juga tidak bisa saling menaklukkan. Hubungan antara agama dan negara yang tidak saling menaklukkan ini tampak dalam hubungan agama dan negara di Indonesia yang berdasarkan Pancasila. Apalagi hubungan antara agama dan negara ini merupakan sebuah kesepakatan bersama. Pertanyaannya kemudian adalah, apakah ada dasar teori hubungan agama dan negara yang didasarkan pada sebuah kompromi bersama sebagaimana dengan ditetapkannya Pancasila sebagai dasar hubungan agama dan negara yang tidak saling menaklukkan? Dan mengapa diskriminasi agama masih saja terjadi di Indonesia?

\section{Temuan mengenai Hubungan Agama dan Negara}

Tesis kematian pelan-pelan dan bertahap dari agama dalam dunia modern telah dikumandangkan sejak zaman pencerahan. Mereka yang 
mendeklarasikan kematian agama itu bukan hanya tokoh-tokoh filsafat yang antiagama, tapi juga tokoh-tokoh antropologi, dan psikologi yang berpendapat bahwa "khayalan-khayalan teologis, ritual liturgis simbolis, dan praktik-praktik sakral adalah produk masa lalu yang akan memudar dalam masa modern." ${ }^{11}$ Ippa Norris dan Ronald Inglehart menjelaskan: "Matinya agama merupakan keyakinan yang luas diterima dalam ilmuilmu sosial selama sebagian besar abad ke-20; tak diragukan, hal itu telah dianggap sebagai model utama dari penelitian sosiologis, di mana sekularisasi disejajarkan dengan birokratisasi, rasionalisasi, dan urbanisasi sebagai revolusi-revolusi historis utama yang mengubah masyarakat agraris lama menjadi masyarakat industri modern".2

Senada dengan hal itu, C. Wright Mills menjelaskan mengenai proses kematian agama ini seperti berikut: “Dunia pernah dipenuhi dengan yang-sakral-dalam pemikiran praktik, dan bentuk kelembagaan. Setelah Reformasi dan Renaisans kekuatan-kekuatan modernisasi menyapu dunia, dan sekulerisasi, sebagai proses historis yang mengikutinya, memperlemah dominasi dari yang sakral. Pada waktunya, yang sakral sepenuhnya menghilang, kecuali mungkin dalam wilayah pribadi". ${ }^{3}$

Berpijak pada tesis kematian agama itulah ketika Perang Dingin berakhir, Francis Fukuyama mendeklarasikan bahwa demokrasi liberal sekuler merupakan sistem politik terbaik yang bisa dicapai manusia. ${ }^{4}$ Tesis kematian pelan-pelan dan bertahap dari agama tersebut ternyata tidak didukung bukti yang kuat. Munculnya spiritualitas New Age yang melanda dunia hingga ke Indonesia, kebangkitan gerakan fundamentalisme agama, hingga munculnya kembali partai-partai keagamaan di Indonesia misalnya, membuktikan bahwa agama tidak

\footnotetext{
1 Ippa Norris dan Ronald Inglehart, Sekularisasi (Jakarta: Yayasan Abad Demokrasi, 2011), 3.

2 Ibid., 3.

3 Ibid., 3.

4 Francis Fukuyama, The End of History and the Last Man (New York: Avon Books, 1992), 338.
} 
pernah mati. Peter L. Berger, salah seorang pendukung teori sekularisasi selama 1960-an, secara dramatis menarik kembali klaim-klaim awalnya: “Dunia sekarang ini dengan beberapa pengecualian, ... amat sangat religius sebagaimana sebelumnya, dan di beberapa wilayah bahkan lebih religius ketimbang sebelumnya. Hal ini berarti bahwa keseluruhan kepustakaan oleh para sejarawan dan ilmuwan sosial yang secara longgar disebut teori sekulerisasi pada dasarnya salah." 5

Selaras dengan Berger, Rodney Stark dan Roger Finke berujar, "Setelah hampir tiga abad melakukan ramalan yang sama sekali salah dan salah menafsirkan baik masa kini dan masa lalu, sekaranglah saatnya untuk menguburkan doktrin sekularisasi dalam makam teoriteori yang salah, dan mendoakannya agar doktrin itu "beristirahat dengan tenang."6

Tesis negara sekuler yang menafikan peran agama jelas perlu ditinjau kembali. Namun, fakta-fakta yang mendasari konsep sekularisasi perlu dipahami secara benar, sehingga pengulangan kesalahan tidak terjadi. Istilah "secular", "secularized" dan "secularization" menurut José Casanova berasal dari kata Latin (zaman pertengahan) "saeculum" yang berarti "dunia”. Dalam Hukum Kanun (Canon Law), sekularisasi merujuk pada suatu "aksi legal" manakala seorang "religius" meninggalkan biara untuk kembali ke "dunia" dengan segala godaannya yang oleh karenanya menjadi manusia "sekuler". Secara Kanonik, para pendeta bisa religius sekaligus sekuler, sehingga pengertian religius tidak selalu berkaitan dengan "dunia lain" (other wordly) melainkan juga suatu cara hidup (a mode of being) di dunia ini. ${ }^{7}$

\footnotetext{
5 "Publik dari hampir semua masyarakat industri maju telah bergerak ke arah orientasi yang lebih sekuler selama 50 tahun terakhir. Meskipun demikian, secara keseluruhan, di dunia sekarang ini, terdapat lebih banyak orang dengan pandangan keagamaan tradisional dibanding sebelumnya, dan mereka merupakan bagian dari populasi dunia yang terus bertambah." Ippa Norris dan Ronald Inglehart, Sekularisasi (Jakarta: Yayasan Abad Demokrasi, 2011), 6 .

6 Ibid., 4.

7 Benyamin F. Intan, Public Religion (New York: Peter Lang, 2006), 13. Lihat juga Yudi Latif, Negara Paripurna (Jakarta: Kompas Gramedia, 2011), 102.
} 
Jadi pemisahan yang sakral dengan sekuler secara total adalah mustahil. Untuk memahami pembedaan sekuler dan yang sakral ini, identifikasi José Casanova terkait tiga makna utama dari agama dalam teori sekularisasi perlu dipahami dengan baik:

(1) sekularisasi sebagai kemunduran agama (secularization as religious decline), yang mengklaim bahwa agama akan terus-menerus mengalami kemunduran di dalam dunia modern sampai pada akhirnya akan lenyap; (2) sekularisasi sebagai privatisasi (secularization as privatization), menyatakan, diferensiasi institusi modern mau tidak mau mengharuskan agama dimasukkan ke dalam wilayah institusionalnya sendiri, karena agama mau tidak mau mengancam struktur-struktur diferensiasi modern; dan (3) sekularisasi sebagai diferensiasi (secularization as differentiation, yang mengacu kepada diferensiasi fungsional dari institusi-institusi religius dari wilayah-wilayah lain di dalam masyarakat modern, khususnya negara, ekonomi, dan ilmu pengetahuan. ${ }^{8}$

Sekularisasi sebagai kemunduran agama (Secularization as religious decline), dan sekularisasi sebagai privatisasi (secularization as privatization), dipegang oleh tokoh-tokoh ilmu-ilmu pengetahuan sosial mulai dari Karl Marx, John Stuart Mill, Auguste Comte, dan Herbert Spencer sampai kepada Emile Durkheim, Max Weber, dan Sigmund Freud. Pandangan

8 Istilah-istilah "sekuler," “disekulerkan," dan "sekularisasi," menurut Casanova, berasal dari kata Latin abad pertengahan saeculum, yang berarti "dunia." Di dalam Hukum Gereja, sekularisasi mengacu kepada sebuah "tindakan legal” di mana "seorang yang 'religius' meninggalkan biara untuk kembali ke 'dunia' dan godaan-godaannya, yang dengan demikian menjadi orang 'sekuler.' Secara aturan, para rahib bisa menjadi 'religius' atau 'sekuler.' Hal ini sangat penting karena dikatakan bahwa "religius" tidak berarti "akhirat"; kata itu berarti cara berada di dalam dunia ini. "Rahib-rahib itu yang telah memutuskan menarik diri dari dunia (saeculum) untuk mendedikasikan diri mereka pada kehidupan kesempurnaan membentuk kerahiban religius. Rahib-rahib itu yang tinggal di dalam dunia membentuk kerahiban sekuler." Max Weber, menurut Casanova, "menyebut sebagai sekulerisasi proses di mana konsep 'panggilan' dialihkan dari wilayah yang religius kepada yang sekuler untuk menunjuk pada ... pelaksanaan kegiatan-kegiatan sekuler di dalam dunia ... Dalam kaitan dengan proses historis yang benar-benar terjadi, istilah 'sekularisasi' pertama kali digunakan untuk menunjuk pada perampasan dan pengambilalihan hak milik besar-besaran, biasanya oleh negara, dari biara-biara, kepemilikan tanah, dan kekayaan abadi gereja setelah Reformasi Protestan dan perang-perang religius yang menyertainya. Sejak saat itu, sekularisasi diartikan sebagai 'jalan,' perpindahan, atau relokasi orang-orang, benda-benda, fungsi-fungsi, makna-makna ... dari lokasi tradisionalnya di dalam wilayah religius ke dalam wilayah-wilayah sekuler." Casanova, Public Religion, 12-3. 
tokoh tokoh tersebut kurang mempunyai bukti empiris karena agama tidak mengalami kemunduran. ${ }^{9}$ Menurut Casanova, sekularisasi sebagai diferensiasi (secularization as differentiation) merupakan pilihan yang tepat. Deprivatisasi agama dalam dunia modern adalah sebuah keharusan. ${ }^{10}$ Menurut Casanova, deprivatisasi agama ini tidak hanya terjadi pada masyarakat-masyarakat Barat, tetapi juga meliputi tradisi-tradisi religius lain juga, seperti Islam, Yudaisme, Hindu, dan Buddha di dalam masyarakat-masyarakat non-Barat. ${ }^{11}$ Berdasarkan temuan Casanova bahwa deprivatisasi agama itu meliputi seluruh dunia dan pada berbagai tradisi religius, maka dapat dipahami tesis kematian agama pelan-pelan dan bertahap patut dipertanyakan. David Hollenbach berpendapat, setiap usaha untuk mendukung teori privatisasi semacam itu sebagai "tujuan normatif" bisa dipertanyakan juga.

Karena di mana agama menjadi selera pribadi tersendiri, kehidupan publik kehilangan kedalaman makna yang bisa menimbulkan kesetiaan dan komitmen di antara para warga negara. Hasilnya yang merupakan anomali bisa menciptakan sebuah ruang hampa di mana kekuatankekuatan fundamentalis bisa masuk ke dalamnya, hampir pasti tanpa

\footnotetext{
9 Jose Casanova menyimpulkan, sejak 1960-an, kepercayaan teori sekularisasi yang menubuatkan pemudaran peran agama (secularization as religious decline) dan privatisasi agama (secularization as privatization) menemukan penyangkalan akibat inkonsistensi dalam teorinya dan kurangnya bukti empiris. Sejak Perang Dunia II, kehidupan agama mengembang di seantero jagad, kecuali Eropa Barat, negara-negara komunis dan beberapa daerah jajahan. Di kawasan bekas komunis, berakhirnya Perang Dingin membawa perubahan baru dalam kehidupan keagamaan. Selang beberapa tahun setelah ambruknya tembok Berlin, penataan politik di Eropa Timur segera disusul oleh ledakan konflik etnoreligius. Dengan demikian dapat disimpulkan bahwa tesis negara sekuler yang antiagama tidak tepat, apalagi ketika pengaruh agama di dunia justru makin menguat.

10 Casanova memberikan lima kajian kasus untuk memberi contoh bagi berbagai bentuk deprivatisasi agama di dalam dunia modern. Dia mengamati peran publik Gereja Katolik di Spanyol (dari gereja negara menjadi bukan gereja negara), di Polandia (dari gereja bangsa menjadi masyarakat madani), di Brazil (dari oligarki menjadi gereja rakyat), dan di Amerika Serikat (dari denominasi privat ke publik) dan juga peran Protestantisme evangelis di Amerika Serikat (dari agama sipil menjadi Kristen Kanan) untuk menunjukkan bagaimana orang-orang Kristen di dalam keempat masyarakat ini telah berdekatan dengan masyarakat sipil di dalam dekade-dekade akhir-akhir ini.

11 Benyamin F. Intan, Public Religion, 13.
} 
kesantunan dan mungkin dengan kekerasan. ${ }^{12}$

Hollenbach dengan demikian setuju dengan tesis sentral Casanova: agama harus dibedakan dari wilayah-wilayah lain kehidupan publik seperti negara. Sekularisasi sebagai diferensiasi meliputi pembedaan wilayah masyarakat di mana agama tidak lagi mendefinisikan "realitas yang meliputi segala sesuatu" di mana ruang sekuler menemukan tempatnya yang tepat. ${ }^{13}$ Mengutip Hollenbach, Benyamin F. Intan menjelaskan, istilah "diferensiasi" seharusnya dipahami sebagai "pembedaan," bukan sebagai "pemisahan ke dalam ruang-ruang yang terpisah ketat."

Diferensiasi agama dan berbagai dimensi kehidupan publik mempunyai konotasi berbeda dengan "pemisahan." Di Amerika Serikat, pemisahan gereja dari negara sering kali disamakan dengan pembatasan agama menjadi sepenuhnya wilayah pribadi yang terpisah dari kekuasaan pemerintah. Berlawanan dengan hal ini, diferensiasi agama dari wilayah kekuasaan negara tidak menyingkirkan semua pengaruh agama di dalam kehidupan publik atau di dalam dunia politik pada umumnya ... Tetapi, pengaruh agama di dalam kehidupan publik dan bahkan politik bisa terjadi bahkan dimana negara dan gereja secara institusi berbeda. Bisa saja terjadi pengaruh publik oleh agama yang diberikan tanpa kontrol negara oleh gereja. Jadi ada pilihan ketiga bagi "integralisme" [kesatuan gerejanegara] di satu sisi dan privatisasi agama di sisi lain. Di dalam pilihan ketiga ini, komunitas-komunitas religius bisa memberikan dampak terhadap kehidupan publik sementara, pada saat yang sama, pelaksanaan agama yang bebas dan bukan sebagai agama negara (non-establishment) sepenuhnya dilindungi. ${ }^{14}$

Sekularisasi yang tidak menyangkali peran agama tidak harus menyebabkan kemunduran agama atau berarti privatisasi agama. Pada sisi lain, modernisasi tidak memiliki hubungan langsung dengan kemunduran agama. Artinya modernisasi tidak menghilangkan agama dalam masyarakat. Tepatnya modernisasi hanya menggeser lokasi sosial

\footnotetext{
Ibid.

13 Ibid.

14 Ibid.
} 
dari agama. Tesis sekularisasi mengenai kematian agama perlu diperbaiki karena agama tidak menghilang, dan tampaknya agama memang tidak mungkin menghilang. Karena itu dalam hubungan agama dan negara seharusnya agama tetap mendapatkan tempat yang terhormat. ${ }^{15}$ Selaras dengan Casanova Yudi Latif menjelaskan:

Bila sekularisasi sebagai proses pemudaran dan pemisahan peran agama (dari negara) tidak memiliki bukti empiris yang kuat, teori modernisasi (termasuk sekulerisasi) menyisakan satu asumsi yang bisa diterima, yakni sekularisasi sebagai proses "pembedaan" (differentiation). Hal ini merujuk pada perbedaan fungsional antara institusi-institusi keagamaan dari ranah lain dalam masyarakat modern, terutama negara, ekonomi dan sains ${ }^{16}$.

Dengan proses diferensiasi sebagaimana dimaksud di atas, terjadi pembedaan antara ranah sosial (social sphere) ke dalam ragam fungsi yang di dalamnya agama tidak lagi menjadi pendefinisi tunggal semua realitas, yang memungkinkan bidang sekuler menemukan tempatnya yang pas, istilah differentiation ini harus dipahami sebagai distinction (pembedaan), bukanlah separation, yang membawa ke arah isolasi secara terpisah. Sebagai realitas politik, konsep ini mengacu pada prinsip distinction antara otoritas agama dan politik, berdasarkan pemahaman bahwa masing-masing terhubung dengan ranah kehidupan yang berbeda

15 1. Negara Ateis Ekstrem. Dasar negara ini tidak percaya pada keberadaan Tuhan Yang Maha Esa. Sikap terhadap agama teoritis diakui kebebasannya, tetapi tidak diperbolehkan adanya propaganda secara resmi menyebarkan agama. Dengan kata lain, kebebasan suatu agama dibatasi. Contohnya negara Komunis. 2. Negara Ateis sekuleristik. Bentuk negara ini berdasarkan ketuhanan dan tidak berdasarkan agama. Sikap terhadap agama praktis diakui kebebasannya dan mengakui pula kebebasan warga negaranya dalam memeluk atau tidak memeluk suatu agama, dan bebas dalam pelaksanaannya. Contohnya negara Liberal. 3. Negara Teis Demokratis. Negara ini berdasarkan ketuhanan, tetapi tidak berdasarkan agama. Sikapnya terhadap agama melindungi dan menjamin agama-agama yang diberi kesempatan yang sama. Negara tidak diatur oleh syariat agama manapun. Contohnya negara Pancasila. 4. Negara Teis Teokratis/negara agama. Negara berdasarkan ketuhanan menurut agama tertentu. Negara ikut mengatur urusan agama dan mewajibkan warga negaranya untuk melaksanakannya. Sebaliknya negara diatur oleh syariat agama tersebut. Contohnya negara Vatikan. Indah Putri Indriany, Pemikiran Politik Islam dan Negara di Indonesia Abdurrahman Wahid (Jakarta: Universitas Indonesia Fakultas: Ilmu Sosial Dan Ilmu Politik Program Pascasarjana, 2002), 72-3.

16 Ibid. 
secara konseptual (meskipun saling berhubungan) dalam tujuan, metode, bentuk pemikiran, wacana dan tindakan.

Yudi Latif, masih mengutip pandangan Casanova, berpendapat bahwa:

Diferensiasi modern menjadi penyangkal dari asumsi pemudaran agama, karena ternyata berperan penting dalam menumbuhkan gairah kegamaan dalam masyarakat modern". Ketika agama terintegrasi dengan negara, represi negara membawa konsekuensi ketidakpercayaan publik pada agama yang dampaknya bertahan lama seperti dalam masyarakat Eropa. Negara teokrasi tidak memperdalam perasaan agama atau memperkuat semangat agama, melainkan mempergunakan agama untuk keperluan Negara". ${ }^{17}$

Dengan adanya diferensiasi, agama bisa mengembangkan otonomi relatif dalam menyediakan landasan moralitas, baik untuk menopang maupun untuk menentang kekuasaan politik. Hal ini memberikan sandaran alternatif bagi warga ketika mengalami kekecewaan atas kekuasaan politik dan dunia kehidupan.

Yudie Latie selanjutnya berpendapat bahwa tersedianya kerangka diferensiasi inilah yang memberi peluang bagi pengembangan "toleransi kembar" antara negara dan agama sehingga bisa mengembangkan peran publiknya masing-masing tanpa saling memaksa karena menemukan konteks keterlibatannya yang tepat. Diferensiasi agama dari domain kekuasaan negara tidak melucuti seluruh pengaruh agama dalam ruang publik. Pengaruh agama dalam kehidupan publik bahkan politik tetap bisa berlangsung ketika negara dan agama berbeda secara institusional. Terbuka peluang bagi pengaruh agama atas negara. Dengan alternatif di luar kerangka integrasi dan separasi ini, komunitas agama tetap bisa memiliki pengaruh publik, berkelindan dengan kewenangan negara untuk mengembangkan institusi-institusi demokratis dalam kerangka konstitusi dan hak-hak asasi manusia. ${ }^{18}$

17 Ibid.

18 Yudi Latief, Negara Paripurna, 109. 


\section{Diferensiasi Agama dan Negara dalam Negara Pancasila}

Pernyataan Indonesia sebagai bukan negara agama dan bukan negara sekuler yang sebelumnya tidak pernah ada, pada awalnya belum mendapatkan landasan teoritis, kecuali sebagai sebuah kesepakatan bersama dari rakyat Indonesia yang beragam agama. ${ }^{19}$ Namun, mengacu pada pandangan Casanova tentang sekularisasi sebagai diferensiasi (secularization as differentiation), jelaslah bahwa pembedaan agama dan negara yang dinyatakan bukan negara agama dan bukan negara sekuler yang menolak agama merupakan jalan tengah yang terbaik untuk menghadirkan kehidupan publik yang baik mendapatkan landasan teoritisnya.

Melihat sejarah ditetapkannya Pancasila di Indonesia sebagai dasar bagi hubungan agama dan negara, harus diakui bahwa hal itu tidak terlepas dari peran aktif agama-agama yang ada di Indonesia. Agama Islam sebagai agama yang dipeluk mayoritas masyarakat Indonesia juga jauh dari monolitis. Demikian juga agama-agama suku yang tersebar di berbagai daerah Indonesia. Semua agama di Indonesia memiliki peran penting dalam sejarah perjuangan kemerdekaan Indonesia.

Penetapan hubungan agama dan negara dalam negara Pancasila merupakan sumbangsih agama-agama di Indonesia yang diakui memiliki peran penting dalam sejarah perjuangan kemerdekaan bangsa Indonesia. Agama Islam, memainkan peran yang sangat krusial di dalam

\footnotetext{
19 Simatupang menerangkan demikian: Negara modern yang bukan negara sekuler, bukan negara agama, dalam arti diidentikkan dengan salah satu agama, tetapi di mana dalam rangka Pancasila, beberapa agama mempunyai kedudukan resmi dan hidup berdampingan bahkan memikul tanggung jawab bersama dalam upaya untuk mendirikan suatu model yang tidak sekuler tetapi tetap menjunjung tinggi nilai moral, etik dan spiritual. Eksperimen yang berlangsung di Indonesia ini tidak ada duanya di negara lain dan sepanjang sejarah umat manusia, dan oleh sebab itu tidak usah mengherankan bahwa upaya untuk menjalankan hal yang belum pernah terjadi itu, tidak selalu mudah. Pihakpihak yang bersangkutan sendiri yaitu golongan-golongan beragama dan berkepercayaan terhadap Tuhan yang Maha Esa, kadang-kadang cenderung untuk kembali ke dalil-dalil yang mereka bawa dari negara asalnya ke Indonesia dan menghadapi masalah-masalah baru. T.B. Simatupang, Membuktikan Ketidakbenaran Suatu Mitos (Jakarta: Pustaka Sinar Harapan, 1991), 236-7.
} 
mendorong nasionalisme Indonesia di awal abad ke-20.20 Muslim Indonesia dalam hal ini harus dipahami dalam keragamannya, karena Muslim Indonesia tidak monolitis.

Gelombang gerakan nasionalis Indonesia juga tidak terlepas dari perjuangan umat kristiani yang juga mengambil bagian di dalam gerakan tersebut. Seperti banyak organisasi nasionalis Indonesia lain, sejak pendiriannya tahun 1925, Partai Katolik telah mendukung gerakan nasionalis. Para pemimpin Indonesia pada waktu itu menyadari agar mereka bisa mencapai kemerdekaan Indonesia, mereka harus bekerja sama dengan organisasi-organisasi politik nasionalis Indonesia lain. Di dalam konteks historis gerakan nasionalis Indonesia ini, muncullah dua kelompok berbeda di dalam wacana politik Indonesia: golongan kebangsaan (secular nationalists) dan golongan Islam (Muslim nationalists). ${ }^{21}$ Kompromi antara kelompok nasionalis sekuler dan nasionalis Muslim dalam pembentukan negara Pancasila yang membedakan agama dan negara ini dijelaskan Supomo demikian:

Menciptakan sebuah Negara Islam di Indonesia berarti mendirikan negara yang akan mengkaitkan negara itu sendiri dengan kelompok yang terbesar, kelompok Islam. Jika sebuah Negara Islam diciptakan di

\footnotetext{
20 Menjadi seorang Muslim berarti orang itu menjadi bagian dari penduduk pribumi apakah Melayu, Jawa atau yang lain. Di antara orang-orang Batak, yang paling tidak mengenal Tuhan, yaitu mereka yang bertobat dari animisme menjadi Islam disebut orangorang Melayu. Hal serupa berlaku bagi orang-orang Cina di Sumatera yang menjadi Muslim. Bernhard Dahm, History of Indonesia in the Twentieth Century, penerj. P.S. Falla (London: Praeger Publishers, 1971), dalam Benyamin F. Intan, Public Religion (Peter Lang: USA, 2006), 159.

21 "nasionalis sekuler" [adalah] sekelompok pemimpin politik Indonesia - Muslim, Katolik, Protestan, Hindu atau yang lain-lain - yang tegas menolak agama sebagai dasar negara, meskipun mereka bukan kaum sekuler secara pribadi, atau juga bukan tidak memiliki sentimen-sentimen, kecenderungan-kecenderungan dan afiliasi-afiliasi religius. Mereka hanya memilih tidak menggunakan agama sebagai ideologi politik atau sebagai sebuah sistem politik, tetapi membatasi agama pada kehidupan pribadi mereka. Sebaliknya, ... "nasionalis Muslim" [adalah] kelompok pemimpin Muslim, yang sangat berkomitmen kepada keyakinan mereka, percaya bahwa Islam harus digunakan sebagai dasar negara. Mereka percaya agama dan negara tidak bisa dipisahkan karena tidak ada pemisahan antara masalah-masalah duniawi dengan urusan-urusan akhirat di dalam ajaran-ajaran Islam. Bernhard Dahm, History of Indonesia in the Twentieth Century, penerj. P.S. Falla (London: Praeger Publishers, 1971), 159.
} 
Indonesia, maka tentunya golongan minoritas akan bangkit, masalah kelompok-kelompok kecil religius, dari kalangan Kristen dan yang lainlain. Meskipun Negara Islam akan melindungi kepentingan-kepentingan kelompok lain sebaik mungkin, kelompok-kelompok religius yang lebih kecil ini tentunya tidak akan bisa merasa terlibat di dalam negara. ${ }^{22}$

Selanjutnya, Supomo menerangkan:

Di dalam negara Indonesia para warga negara harus didorong untuk mencintai tanah leluhurnya, untuk memberikan diri mereka kepada dan mengorbankan diri mereka demi negara, untuk melayani dengan senang tanah leluhur, untuk mencintai dan melayani para pemimpin mereka dan negara, untuk tunduk kepada Tuhan, untuk memikirkan Tuhan setiap saat. Semua hal ini harus terus-menerus didukung dan digunakan sebagai dasar moral bagi negara kesatuan nasional ini. Dan saya yakin bahwa Islam akan memperkuat prinsip-prinsip ini. ${ }^{23}$

Dari awal masa pra-kemerdekaan Indonesia, agama-agama berperan penuh dan memberikan sumbangsih-sumbangsih utama bagi pembentukan nasionalisme Indonesia. Inspirasi agama adalah salah satu faktor terpenting yang mendukung gerakan nasionalis Indonesia dengan mendukung kesatuan nasional melawan penjajahan Belanda.

Mengenai hubungan antara agama dan negara, Darmaputera, seorang teolog Kristen menjelaskan demikian:

Negara mengakui otonomi agama, dan agama mengakui otonomi negara. Masing-masing tidak mencampuri langsung urusan dan otoritas yang lain. Namun demikian, antara keduanya terdapat keterkaitan fungsional. Tanpa mencampuri secara langsung urusan-urusan internal keagamaan, negara mempunyai tanggung jawab keagamaan yaitu melindungi dan membantu agar semua agama hidup dan berkembang dan menjamin baik kebebasan maupun kerukunan hidup beragama. Di pihak lain, tanpa mencampuri secara langsung urusan-urusan kenegaraan (termasuk di sini pemaksaan kehendak dengan melalui kekuatan massa), agama mempunyai tanggung jawab kenegaraan. Tanggung jawab ini adalah meletakkan kerangka landasan moral, etik dan spiritual bagi, pembangunan nasional sebagai pengamalan Pancasila. Tanggung jawab

22 B.J. Boland, The Struggle of Islam in Modern Indonesia (The Hague: Martinus Nijhoff, 1971), 20.

23 Ibid. 
yang harus dilaksanakan secara terus menerus dan bersama-sama, artinya, kerangka landasan moral etik dan spiritual itu tidak hanya kontribusi satu agama saja. ${ }^{24}$

Pancasila sebagai kristalisasi kehidupan masyarakat Indonesia terbukti mampu menaungi semua, karena ia adalah isi dari jiwanya bangsa Indonesia, kesepakatan bersama rakyat Indonesia. Soekarno mengakui bukan pembuat Pancasila, tetapi menggali di dalam buminya rakyat Indonesia. Pancasila sebagai nilai-nilai yang universal diterima sebagai kompromi kelompok-kelompok yang ada di Indonesia. Penerimaan Pancasila tidak akan menghapuskan identitas yang ada.

Hubungan antara agama dan negara di Indonesia telah dirumuskan dengan jelas. Ungkapan Indonesia bukan negara agama dan bukan negara sekuler yang unik itu didasarkan pada Pancasila. Bentuk negara Pancasila yang dimaksud dalam hal ini adalah negara yang memisahkan antara agama dan negara. Negara Pancasila bukan negara sekuler dan juga bukan negara agama, namun negara memberikan perlindungan terhadap agama, serta memperlakukan agama-agama secara sama dalam hukum dan perundang-undangan yang berlaku yang bersumber pada Pancasila dan UUD 1945.

\section{Ambiguitas Diferensiasi Agama dan Negara di Indonesia}

Agama dan negara berbeda. Agama tidak boleh menguasai negara, demikian juga negara tidak boleh menyingkirkan peran agama di tengah masyarakat. Agama dan negara mempunyai hubungan yang bersifat koordinasi. Agama bertanggung jawab untuk mengingatkan negara apabila negara tidak melakukan kewenangannya sebagaimana kodratnya. Karena agama-agama adalah pemberi landasan moral, demikian juga pada waktu agama-agama dalam interpretasi praktis keagamaannya melanggar undang-undang dan ketertiban umum. Maka

24 Trisno Sutanto, "Mengelola Kemajemukan" dalam Eka Darmaputera (ed), Pergulatan Kehadiran Kristen Di Indonesia (Jakarta: BPK Gunung Mulia, 2001), 97. 
negara wajib untuk melakukan tindakan hukum untuk penertiban hubungan bersama antaragama dan kelompok yang ada.

Realitas hubungan agama dan negara di Indonesia tidak selalu berjalan pada jalan yang telah ditentukan. Setidaknya itu terlihat jika diukur berdasarkan skala kebebasan beragama yang dikembangkan berdasarkan 20 kriteria yang dimuat dalam Laporan Departemen Luar Negeri Amerika Serikat tentang Kebebasan Keagamaan Internasional, 2002.25 Skala tersebut mewakili versi yang diperluas dari skala Chaves dan Cann 1992 yang digunakan untuk mengukur peraturan negara dalam 18 masyarakat pasca-industri.

1. Konstitusi membatasi kebebasan beragama.

2. Konstitusi tidak mengakui kebebasan beragama. (Atau hukum tidak mengakui kebebasan beragama, dalam sebuah negara yang tidak memiliki konstitusi tertulis).

3. Terdapat sebuah gereja resmi negara.

4. Negara mendukung satu agama.

5. Organisasi-organisasi keagamaan harus mendaftar pada negara atau disahkan oleh negara untuk bisa beroperasi secara legal, atau pemerintah memberlakukan berbagai kekangan pada organisasi-organisasi yang tidak terdaftar atau diakui.

6. Negara mengeluarkan izin hukum bagi bangunan-bangunan keagamaan.

7. Negara mengangkat atau menyetujui para pemimpin gereja, para pemimpin gereja mengangkat atau menyetujui para pejabat pemerintah, dan/atau para pemimpin gereja memiliki posisi khusus dalam pemerintahan.

8. Negara memberikan gaji gereja secara langsung.

9. Negara mensubsidi beberapa/ semua gereja.

10. Negara memberikan potongan pajak bagi beberapa/ semua gereja.

25 Pippa Noris dan Ronald Inglehart, Sekularisme, 299-300. 
11. Negara melarang pendeta/pemimpin agama dari semua/ beberapa agama tertentu untuk memegang jabatan publik.

12. Negara memiliki sebagian properti dan bangunan-bangunan gereja.

13. Negara memerintahkan pendidikan keagamaan di sekolahsekolah negara, meskipun pelajar dapat dibebaskan dari kewajiban ini dengan permintaan orangtua.

14. Ada laporan-laporan tentang konversi keagamaan yang dipaksakan.

15. Negara melarang beberapa kelompok keagamaan, perkumpulan keagamaan, atau sekte.

16. Negara mengekang/ melarang para misionaris memasuki negara tersebut untuk tujuan-tujuan menarik pemeluk baru.

17. Negara mengekang/ menyensor beberapa kepustakaan keagamaan yang masuk atau beredar di negara tersebut.

18. Negara memenjarakan atau menahan beberapa kelompok keagamaan atau individu-individu.

19. Negara gagal mencegah konflik-konflik dan kekerasan etnoreligius yang serius yang dilakukan terhadap beberapa ke lompok minoritas.

20. Negara tersebut disebut sebuah negara khusus dalam hal kebebasan beragama oleh Departemen Luar Negeri Amerika Serikat. $^{26}$

Ambiguitas kebijakan diferensiasi agama dan negara di Indonesia terlihat pada beberapa hal antara lain: Negara mendukung beberapa agama, dan tidak mendukung beberapa agama termasuk agama-agama suku atau kepercayaan meski tetap memberikan hak hadir di bumi Indonesia (4). Organisasi-organisasi keagamaan harus mendaftar pada negara atau disahkan oleh negara untuk bisa beroperasi secara legal, atau

26 Ibid. 
pemerintah memberlakukan berbagai kekangan pada organisasiorganisasi yang tidak terdaftar atau diakui. 6. Negara mengeluarkan izin hukum bagi bangunan-bangunan keagamaan. Di Indonesia aturan ini telah digunakan menjadi alat untuk menutup rumah ibadah yang bermasalah dalam perizinan dan yang tidak memiliki izin. 7. Negara memberikan gaji gereja secara langsung. 9. Negara mensubsidi beberapa/ semua agama (negara memberikan bantuan terhadap agama tertentu) 10. Negara memberikan potongan pajak bagi beberapa/semua agama. 13. Negara memerintahkan pendidikan keagamaan di sekolah-sekolah negara, meskipun pelajar dapat dibebaskan dari kewajiban ini dengan permintaan orangtua. 14. Ada laporan-laporan tentang konversi keagamaan yang dipaksakan. 15. Negara melarang beberapa kelompok keagamaan, perkumpulan keagamaan, atau sekte. 16. Negara mengekang/melarang para misionaris memasuki negara tersebut untuk tujuan-tujuan menarik pemeluk baru. 17. Negara mengekang/menyensor beberapa kepustakaan keagamaan yang masuk atau beredar di negara tersebut. 18. Negara memenjarakan atau menahan beberapa kelompok keagamaan atau individu-individu. 19. Negara gagal mencegah konflikkonflik dan kekerasan etnoreligius yang serius yang dilakukan terhadap beberapa ke lompok minoritas.

Berdasarkan skala di atas, jelaslah bahwa kebijakan terkait agama di Indonesia tidak sesuai dengan kebijakan Pancasila yang membedakan agama dan negara. Karena negara terlihat dalam undang-undang dan peraturan turunannya tidak mengacu pada Pancasila. Ambiguitas kebijakan tersebut membuat hubungan antara agama dan negara, agama dan agama atau toleransi kembar tidak terimplementasi dengan baik. Ambiguitas ini terjadi karena adanya keragaman apresiasi terhadap Pancasila. Ketidakpuasan individu atau kelompok yang ada bukan karena Pancasila tidak mampu menjadi payung atas semua orang yang berada di Indonesia, tetapi kelompok-kelompok yang tidak puas tersebut selalu ingin menguasai negara, apalagi pemerintah yang ada sering kali tidak konsekuen melaksanakan Pancasila dan UUD 1945. 
Ketidakpuasan kelompok-kelompok tersebut kemudian mengarah pada usaha menggantikan Pancasila sebagai ideologi dan dasar negara. Baik dengan cara terselubung yaitu melakukan penetrasi nilai-nilai agamanya ke dalam Pancasila, atau dengan cara kekerasan melalui pemberontakan untuk menumbangkan kekuasaan negara. Keberhasilan Pancasila dalam mempersatukan bangsa Indonesia, serta mempertahankan kedaulatan negara Indonesia tersebut tidak diakui oleh semua kelompok yang ada di Indonesia. Fakta bahwa Pancasila belum dianggap sebagai sesutau yang final sebagai dasar dan ideologi negara nyata dengan adanya pemberontakan-pemberontakan yang ingin menggantikan Pancasila dengan ideologi lain.

Di penghujung pengakuan kedaulatan Negara Kesatuan Republik Indonesia (NKRI) timbullah pemberontakan-pemberontakan yang ingin menggantikan Pancasila dengan ideologi lain, yaitu ideologi Islam dan Komunis. Pemberontakan tersebut dapat dipadamkan walaupun diperlukan waktu yang lama, jauh lebih lama dari perang mempertahankan kemerdekaan Indonesia. Jika perang mempertahankan kemerdekaan telah selesai pada tahun 1949 (5 tahun), maka perang untuk memadamkan pemberontakan yang dilakukan DI berlangsung selama 13 tahun. Pemberontakan-pemberontakan yang dilakukan Komunis dan DI merupakan bukti adanya harapan-harapan lain di luar Pancasila. Harapan-harapan tandingan terhadap Pancasila seharusnya tidak perlu ada, karena merupakan pengingkaran konsensus bersama yang dinyatakan dalam ikrar kemerdekaan. Adanya harapan-harapan tandingan di luar Pancasila merupakan bukti bahwa tidak semua individu memegang komitmen terhadap Pancasila. Kegagalan memegang komitmen bersama untuk hidup bersama dalam negara Pancasila ini akhirnya melahirkan keragaman apresiasi terhadap pancasila. Pertumbuhan kelompok-kelompok yang ada dalam naungan Pancasila tidak boleh bertentangan dengan semangat Pancasila yang mempersatukan kelompok-kelompok yang ada. 
Lahirnya otonomi daerah di era reformasi ternyata menimbulkan persoalan baru, khususnya dalam hubungan antaragama. Daerah dengan mayoritas agama tertentu kemudian menuntut kekhususannya meski harus mendiskriminasikan agama-agama lain. Peraturan daerah (perda) agama pun muncul di berbagai tempat dan mengancam kebebasan beragama. Kehadiran perda-perda bernuansa agama pada umumnya tidak secara terang-terangan menamakan dirinya sebagai perda agama, namun isinya yang memuat nilai-nilai agama tertentu dan terindikasi mendiskriminasikan agama-agama lain mengidentikkan dirinya sebagai perda agama, biasa juga disebut perda yang melanggar hak-hak asasi manusia. Perda bernuansa agama itu sukses diberlakukan di beberapa provinsi di Indonesia, setidaknya itu telah ditetapkan di 13 provinsi di Indonesia. ${ }^{27}$

Sifat diskriminatif yang melekat pada perda-perda agama itu menimbulkan perlawanan dari mereka yang terdiskriminasikan, namun perda-perda agama tersebut terus saja melenggang sambil mengklaim diri terlahir secara demokratis. Apalagi ketika demokrasi direduksi hanya pada pemilihan berdasarkan suara terbanyak. Diskriminasi yang dihadirkan oleh perda agama Islam kemudian memicu lahirnya raperda bernuansa agama Kristen. Meskipun raperda bernuansa agama Kristen tersebut tidak pernah ditetapkan sebagai kebijakan daerah karena tidak disetujui mayoritas.

Ambiguitas diferensiasi negara dan agama di Indonesia terjadi karena pembuatan kebijakan publik terkait agama sering kali gagal untuk tunduk pada prinsip-prinsip public reason dan public deliberation. Dalam negara Pancasila, ajaran keagamaan boleh saja memberikan inspirasi, namun formulasinya harus mengalami proses substansial

\footnotetext{
27 Perda berbasis syariat itu setidaknya dapat diklasifikasikan ke dalam tiga hal, yaitu: (i) ketertiban masyarakat seperti pelarangan aktivitas pelacuran dan pembatasan distribusi konsumsi minuman beralkohol; (2) Kewajiban dan keterampilan keagamaan seperti pembayaran zakat dan kemampuan baca Alquran; dan (3) simbolisme keagamaan berupa pakaian busana Muslim. Arskal Salim, "Perda Berbasis Agama dan Perlindungan Konstitusional Penegakan HAM" (Jurnal Perempuan, No. 60/September 2008).
} 
(tidak secara literer merujuk pada kitab dan doktrin keagamaan) guna memenuhi legitimasi demokratis yang bersifat rasional dan imparsial. Ini dapat dipahami karena keputusan publik-politik dianggap rasional imparsial jika didasarkan pada fakta (bukan doktrin semata), dan diorientasikan bagi kepentingan banyak orang dan jangka panjang, serta melibatkan partisipasi semua kalangan secara inklusif. Sehingga tidak satu agama dapat mengklaim bahwa kebijakan publik itu adalah hasil penguasaan kelompok agama tertentu.

\section{Penutup}

Menata hubungan agama dan negara dalam sebuah negara Indonesia yang beragam memang bukan merupakan suatu hal yang mudah. Karena semua agama merasa memilki jalan terbaik untuk terciptanya hubungan antaragama dalam sebuah negara yang beragam. Apalagi pada daerah-daerah di mana konflik bernuansa agama telah terjadi. Konflik kekerasan antaragama itu telah menimbulkan kecurigaan antarpemeluk agama yang berbeda, dan perasaan curiga tersebut tidak mudah dihapuskan. Oknum-oknum yang terlalu lama menikmati kekuasaan dengan memanfaatkan agama tidak dengan sendirinya akan melepaskan nikmatnya kekuasaan tersebut. Namun perjuangan semua rakyat Indonesia yang menyadari arti pentingnya negara Indonesia bagi mereka menjadi modal dalam usaha mencapai Indonesia yang lebih baik.

Apabila perjuangan semua rakyat Indonesia yang beragama adalah perjuangan untuk pengamalan Pancasila yang murni dan konsekuen, dengan semangat yang inklusif bagi terbentuknya demokrasi yang berkeadilan, maka peran agama-agama tidak akan berubah menjadi usaha untuk saling menguasai dengan memakai negara sebagai senjata untuk meredam sesamanya. Perjuangan tersebut seharusnya menjadi perjuangan yang suci menghargai keragaman agama-agama yang adalah realitas Indonesia. Pancasila adalah dasar yang kokoh bagi negara demokrasi yang menghargai pluralisme agama. Demokrasi yang menghargai pluralisme agama ini adalah pilihan terbaik untuk 
Indonesia, dan juga bangsa-bangsa di dunia.

Negara Pancasila yang membedakan agama dan negara sejalan dengan teori Casanova secara bersamaan juga menyempurnakan demokrasi Barat yang sekuler, yang meminggirkan agama. Salah satu negara di dunia yang menganut pemerintahan demokrasi yang tidak meminggirkan agama adalah Turki, negara ini terus mengembangkan demokrasi yang tidak didasarkan agama dan juga bukan negara sekuler yang menolak agama. ${ }^{28}$ Demokrasi sekuler yang meminggirkan agama saat ini semakin ditolak seiring tuduhan bahwa sekularisme adalah juga agama, meski ide sekularisme sebagai agama itu sendiri merupakan paradoks. ${ }^{29}$

Pancasila merupakan kesepakan bersama agama-agama di Indonesia untuk menaungi semua agama-agama yang beragam di Indonesia. Model pemerintahan negara Pancasila ini dapat menjadi contoh bagi negara-negara lain dalam menentukan hubungan ideal antara agama dan negara. Pancasila adalah negara pluralisme agama yang memposisikan agama-agama pada tempat terhormat tanpa mendiskriminasikan agama tertentu. Perjalanan negara Pancasila itu tidak selalu mulus, bahkan tidak jarang ditemukan konflik suku, agama, ras dan antargolongan hingga dalam skala besar. Namun, semua itu terjadi karena terjadinya keragaman apresiasi terhadap Pancasila, bukan karena kelemahan yang ada pada diri Pancasila.

28 James W. Skillen, The Good of Politics (Grand Rapids, Michigan: Baker Academic, 2014), 193.

29 Ibid., 192. 